\title{
The Calendar and the Time Account of the Turko-Tatars
}

\author{
Gamirzan M. Davletshin ${ }^{1}$ \\ ${ }^{1}$ Kazan (Volga Region) Federal University, Kazan, Russia \\ Correspondence: Gamirzan M. Davletshin, Kazan (Volga Region) Federal University, 420008, Kazan, \\ Kremlyovskaya Street 18, Russia. E-mail: g.davletshah@mail.ru
}

Received: June 2, 2015 Accepted: June 15, 2015 Online Published: June 29, 2015

doi:10.5539/jsd.v8n5p205 URL: http://dx.doi.org/10.5539/jsd.v8n5p205

\begin{abstract}
The relevance of the studied problem is caused by the fact that the identity of this or that nation is reflected first of all in its traditional culture which indissoluble areas are the calendar and the time account. Without studying this sphere of knowledge of national culture it is impossible to understand not only spiritual but also material, social life in the Turko-Tatar societies. The purpose of this article is the identification and the analysis of the facts of a calendar of the Turko-Tatars in close relationship with other areas of their spiritual culture. The leading method to the study of this problem is a complex method. The use of a complex method for us is not only a means of bringing in one research of diverse material as rather the principle of mutual validation and correlation of the facts and the objectivity of the conclusions. The main results of this article are detection of features and nature of the calendar of the Turko-Tatars, their role of public and spiritual life in interrelation with cultures of the Central Asian, the Muslim states. The article can be useful for historians, culturologists in research of culture, scientific knowledge, and socio-economic phenomena of the Turko-Tatars.
\end{abstract}

Keywords: calendar, metrology, system of the account, linear measures, units of measure, size

\section{Introduction}

\subsection{Background}

The nature of the Turko-Tatar calendar, chronology was determined by the needs of nomadic and later agricultural economy, cultural ties with other countries, religion and traditions.

Centuries-old life of the ancestors of the Tatar people (Huns/Huns, the ancient Turks, Khazars, Bulgars, Cumans, population of the Golden Horde, Kazan and other Tatar khanates) and their economic activities should have been reflected in their calendars. Needs of constant development of production and extensive trade and cultural ties have led to development of various methods of counting time.

\subsection{Discussion and Status of a Problem}

Folk knowledge is reflected in the researches of the ethnographer G.M. Khisamutdinov, who mentions the issues of the calendar of the Tatars in historical aspect. Based on indirect data, he notes the practice of a twelve-year animal cycle by the Bulgarians, as well as the Muslim lunar and zodiac calendars (Khisamutdinov, 1967). Although the facts presented by G.M. Khisamutdinov are later in time than the history of the Tatar spiritual culture, his materials can be used in the reconstruction of the ancient and medieval system of the time account (Khisamutdinov, 1967).

These questions are more profoundly taken up in the writings of the scientific mathematician V.M. Berkutov who collected and analyzed a large amount of material.

Based on the writings of Sh. Mardzhani and others, he notes the existence of different calendar systems of the Bulgarians. For the sake of justice it is necessary to indicate that insufficient critical analysis of the sources of the ancient period has led him to some unreasonable conclusions (Berkutov, 1987).

However the calendars and the time account of the Turko-Tatars have not yet become objects of special and complex research, as indissoluble areas of spiritual culture of the Turko-Tatars.

\section{Materials and Methods}

In this article, the ancestors of the Tatar people we conventionally call the Turko-Tatars. The term "Turko-Tatars" as the generic name of all Turkic people came into use in the XIX - early XX centuries. By this term we 
conventionally mean the population of a vast territory during the period from the ancient Turkic time before the formation of the Volga (Kazan) Tatars.

\subsection{Sources}

\subsubsection{Written Sources}

When working with this theme we identified and used different types of sources: written, physical (archaeological), ethnographic, folklore, language, etc. Written sources are represented mainly by the works of the Arab and Persian authors, Chinese, Russian, Turko-Tatar compositions, literary works of authors of the Volga Bulgaria, the Golden Horde and the Kazan khanate.

\subsubsection{Archaeological Materials}

Important, sometimes the only, especially for the ancient periods of the archaeological sources are materials that allow not only to clarify information recorded in the written sources, but sometimes in new ways to reveal those or other phenomena of spiritual culture. A large amount of the archaeological material relating to the ancient Turkish, Bulgarian, Golden era and the period of the Kazan khanate was studied.

\subsubsection{Ethnographic Data}

Ethnographic data are essential to our study.

Ethnographic materials of Tatar and other nations which are in close ethnic and cultural ties with the Turko-Tatars testify to preservation of surprising parallels of ethnographic property. Careful examination of these parallel phenomena provides an opportunity to close the facts recorded in historical ethnography with archaeological data or written sources.

\subsubsection{Linguistic Materials}

To a certain extent the data of linguistics were also used. Etymological, semantic analysis of words, historical terms related to the field of ancient calendars and the system of the time account in some cases was possible to associate with certain periods of history.

\subsection{Research Methods}

A comprehensive study of different sources gives the chance to find the answers to the questions raised in this work. The use of the complex method for us is not only means of attraction in one research of diverse material, but also the principle of mutual check of reliability of the facts and objectivity of the received conclusions.

In addition to the basic method of analysis of the study there are involved the following:

- the comparative-historical method of examining the possibility of a greater number of involved materials, their representativeness with certainty in temporal, spatial and ethnic relations;

- historical and genetic analysis, which represents an excursus into the history of the Turko-Tatars and their ancestors or tribes, the people living in close contact with them;

- the interpolation method allowing to compare the phenomena of culture of those countries with whom the Turko-Tatars supported close economic, commercial and cultural ties with the local Finno-Ugric people and the countries of the East.

\section{Results}

\subsection{The Calendar and the Time Account}

\subsubsection{Ancient Roots}

The ancient Turks conducted the chronology from "the creation of the world."

The Great steppe also became a peculiar natural calendar: nomads possessed rich information about the nature of the steppes, animals that became for them the temporary benchmarks. In ancient Turkic runic monuments a month of summer (July) and a month when the deer jumps in the mountains (August) are recorded (Malov, 1959). Also "the live chronology" was practiced, when a lifetime of the well-known persons was taken as a temporary reference point (Malov, 1952).

Initially the annual calendar of the ancient Turks consisted only of ten months and their names coincided with ordinal numerals (Melioransky, 1899). The first month of the Turkic calendar coincided with the third month of the Chinese calendar. The first two months respectively were called "big and small months." This ancient calendar was practiced among the Turkic people, including the Bulgarians and the Tatars, quite a long time.

The ancient Turks were familiar with the Manichean and the Babylonian, the ancient Syrian, the Nestorian 
calendars.

\subsubsection{The Old Turkic "Animal Cycle"}

From the VIII century in the Turkic Kaganate the so-called Turko-Mongolian duodecimal animal calendar based on the Ancient Chinese began to be applied. Days and months on the "animal cycle" were called as the corresponding ordinal numerals. Besides, the ancient Turks calculation of days was conducted on the basis of the name and sequence of the animals that appear in the cycle (see: Old Turkic dictionary, 1969; Tikhomirov, M. N. (1946); Biruni, A. (1957). For example, the year of the Leopard, the fifth month of the year of the Chicken. Therefore, for the ancient Turks a cycle of 12 days was a certain period of time like a decade, week.

From the proto Bulgarian time and era of the ancient Turks Bulgarians inherited a calendar of "animal cycle" (see.: table 1). "Imennik of the Bulgarian princes" in which the names of ten years of a twelve-year animal cycle are recorded testifies the use of the account of years on the basis of this cycle by proto Bulgarians (Mikolla, 1916).

The duodecimal animal calendar subsequently practiced at the Khazar, proto Bulgarians, Danube and the Volga Bulgars, in the Golden Horde and the Kazan khanate and existed prior to the beginning of the XX century. A desire to bring the "animal cycle" to local conditions is observed at a number of the people. That can be seen at the Danube Bulgaria. The names of the years are replaced by names of the animals of local fauna (Tiger-Leopard, Dragon-Fish, Crocodile-Dragon, Monkey-Hedgehog, Pig- Elephant, the Mouse-Camel, etc.).

In the pre-Mongolian time among the Turkic-speaking people legends, signs associated with the appearance and existence of the 12-year "animal cycle" were widespread. The tribes and nations that used the twelve-year animal cycle attributed to each year specific features. Depending on the name of year they predicted productivity or hunger, wellbeing or misfortune.

In due time, generalizing these signs, A.N. Samoylovich wrote: "Signs of our written sources concern not so much stock-nomadic life which is typical for most of the ancient Turkish people, except the Uighurs and Kama Bulgarians, how many agricultural and settled culture with the cities and trade" (Samoylovich, 1927). A. N Samoylovich's conclusion quite corresponds to that way of life which was conducted by the people using this calendar.

Table 1. Comparative table of the names of the years of the Turko-Mongolian "animal calendar"

\begin{tabular}{|c|c|c|c|c|c|c|c|c|}
\hline Ancient Turks & $\begin{array}{l}\text { Biruni } \\
1000 \\
\text { year }\end{array}$ & $\begin{array}{l}\text { Kashgari } \\
1073 \text { year }\end{array}$ & $\begin{array}{l}\text { «Imennik» } \\
866 \text { year }\end{array}$ & Tatar & Chuvash & Balkarokarachai & Mongol & $\begin{array}{l}\text { Russian translation and } \\
\text { differences }\end{array}$ \\
\hline 1.Syichkan & Sichkan & Syichgan & Somor & $\begin{array}{l}\text { Tyichkan, } \\
\text { Syichkan }\end{array}$ & $\begin{array}{l}\text { Kushak } \\
\text { kay }\end{array}$ & Chichhan & Hulgana & $\begin{array}{l}\text { Myish } \\
\text { the literal translation into } \\
\text { English: Mouse }\end{array}$ \\
\hline 2. Уд & Од & Уд & Шегор, & Сыер, & Ёне & Ийнек & Ухэр & Korova, mong. - Byik \\
\hline $\mathrm{Ud}$ & Od & $\mathrm{Ud}$ & $\begin{array}{l}\text { Сигор } \\
\text { Shegor, } \\
\text { Sigor }\end{array}$ & $\begin{array}{l}\text { Сыгыр } \\
\text { Syier, } \\
\text { Syigyir }\end{array}$ & Ėne & Ijnek & Ukhehr & $\begin{array}{l}\text { the literal translation into } \\
\text { English: Cow, mong. - } \\
\text { Bull }\end{array}$ \\
\hline 3. Bars & Bars & Bars & Ver & $\begin{array}{l}\text { Bars } \\
\text { Baryis }\end{array}$ & Pars & K'aplan & Bars & $\begin{array}{l}\text { Bars, balkaro.-karachai .- } \\
\text { Tigr, } \\
\text { «Imennik»-Volk } \\
\text { the literal translation into } \\
\text { English: Bars, } \\
\text { balkaro.-karachay. } \\
\text { Tiger "Imennik"- Wolf }\end{array}$ \\
\hline 4.Tavshan & Tushkan & Tavyiggan & $\begin{array}{l}\text { Dvansh, } \\
\text { Dovshon }\end{array}$ & $\begin{array}{l}\text { Kuyan, } \\
\text { Taushan }\end{array}$ & Mulkach & K'on & Tuulay & $\begin{array}{l}\text { Zayats } \\
\text { the literal translation into } \\
\text { English: Hare }\end{array}$ \\
\hline
\end{tabular}




\begin{tabular}{|c|c|c|c|c|c|c|c|c|}
\hline Ancient Turks & $\begin{array}{l}\text { Biruni } \\
1000 \\
\text { year }\end{array}$ & $\begin{array}{l}\text { Kashgari } \\
1073 \text { year }\end{array}$ & $\begin{array}{l}\text { «Imennik» } \\
866 \text { year }\end{array}$ & Tatar & Chuvash & Balkarokarachai & Mongol & $\begin{array}{l}\text { Russian translation and } \\
\text { differences }\end{array}$ \\
\hline $\begin{array}{l}\text { 5. Лэу } \\
\text { Leu }\end{array}$ & Luy & Nek & & $\begin{array}{l}\text { Azhdaha, } \\
\text { Leu, } \\
\text { Kelte }\end{array}$ & Arslan & Chabak' & Luu & $\begin{array}{l}\text { Drakon } \\
\text { balkaro.-karachay.-Ryiba, } \\
\text { M.Kashgari-Krokodil } \\
\text { the literal translation into } \\
\text { English: Dragon } \\
\text { balkaro.-karachay.-Fish, } \\
\text { M.Kashgari-Crocodile }\end{array}$ \\
\hline 6. Elan & Iilan & Elan & $\begin{array}{l}\text { Dilom, } \\
\text { Dilan }\end{array}$ & Elan & Çè & Zhilan & Mogay & $\begin{array}{l}\text { Zmeya } \\
\text { the literal translation into } \\
\text { English: Snake }\end{array}$ \\
\hline 7. Yund & Yunt & Yund & Moren & Elkyi & $\mathrm{Ut}$ & At & Morin & $\begin{array}{l}\text { Loshad } \\
\text { the literal translation into } \\
\text { English: Horse }\end{array}$ \\
\hline 8. Koy & Kuy & Koy & $\begin{array}{l}\text { Tekuchitem, } \\
\text { Kuchin. }\end{array}$ & Kuy & Surah & K"oj & Honin & $\begin{array}{l}\text { «Imennik»-Baran } \\
\text { the literal translation into } \\
\text { English: «Imennik»- } \\
\text { Sheep }\end{array}$ \\
\hline 9. Bichin & Pichin & Bichin & & $\begin{array}{l}\text { Bichen, } \\
\text { Maymyil, } \\
\text { Kerpe }\end{array}$ & Pesin & Maymul & Mechin & $\begin{array}{l}\text { Obezyana, tatar--Ezh } \\
\text { the literal translation into } \\
\text { English: Monkey, } \\
\text { tatar-- Hedgehog }\end{array}$ \\
\hline 10.Takyigu & Tagigu & Takagu & Toh, Tokol & Tavyik & Chah & K'ush, Tauuk & Tahla & $\begin{array}{l}\text { Kuritsa, balkaro.- } \\
\text { karachay.-Ptitsa } \\
\text { the literal translation into } \\
\text { English: Chicken, } \\
\text { balkaro.-karachay. - Bird }\end{array}$ \\
\hline 11. It & It & Yit & Eth & Et & Yyita & It & Nohay & $\begin{array}{l}\text { Sobaka } \\
\text { the literal translation into } \\
\text { English: Dog }\end{array}$ \\
\hline 12.Tonuz & Tunguz & Tonuz & Doks & Dungyiz & Syisna & Tonguz & Gahai & $\begin{array}{l}\text { Svinya } \\
\text { the literal translation into } \\
\text { English: Pig }\end{array}$ \\
\hline
\end{tabular}

The table is compiled according to: Abureyhan Biruni (1957), Mahmud Kashgari (1960), I. I. Mikolla (1916), "the Ancient Turkic dictionary" (1969), A. N. Samoylovich (1927), O. L. Opryshko (1967), V. D. Dimitriev (1982) and others.

\subsubsection{Bulgarian-Khazar Calendars}

The original calendar was common for the Khazar-Bulgarians. It was based on the division of the year into four equal parts. According to V.E. Flerova (Flerova, 1997), one of such chronology was built on the principle of contrasting light and darkness and equal, more often fourfold, division of the year. It is reflected in the bronze rings divided by the heads of cyclic animals into four parts. In the most of amulets the heads are turned to the right, i.e. move in the direction of the movement of the sun. There are also the heads turned to the opposite side. 
They represent the movement of the "night sun". Its reflection we see on the ring amulets which are found in later works (in the XIII-XVI centuries in the Kamayevsky settlement of Tatarstan).

Round metal plates in which animals of a twelve-year cycle are represented on bronze circles - mirrors going in a consecutive order one after another can be met. The images symbolize the idea of infinity of time, having neither beginning nor end. On the Bulgarian subjects with the years of the twelve-year cycle, images of certain animals are observed (dog, leopard, dragon, hare, sheep, chicken, mouse). The latter, obviously, were worn by people born in the respective year. They believed in their patronage and protect power.

The above-described systems of chronology infiltrated the Bulgarians from outside, or were inherited from their predecessors. The Bulgarians, obviously, had their own national calendars, partially they remained at the Tatars and the people, next to them (see tab.). The name "bilekaye" — "fifth month" (bial/bish) in the table indicates that the Bulgarians, like the ancient Turkic people and the proto Bulgarians (Mikolla, 1916), once had a calendar based on ordinal numerals.

There is evidence that the Bulgarians had other types of calendar. Together with the penetration of Islam the Muslim lunar calendar - lunar Hejira began to spread among the Bulgarians. It became in the Volga Bulgaria one of the attributes of the Muslim religion and the official calendar.

Under the title "Persian notation" ("farsiyahisaby") one of the Iranian calendars means. In the Bulgarian times till 1079 in the East the Iranian calendar on an era of Yezdegerd was used. Then with the assistance of the outstanding Persian mathematician, astronomer, poet and philosopher Omar Khayyam (1040-1143) it was reformed. The chronology on this calendar was adopted in the state of Seljuk and therefore has been called the era of Jalal al-Din on behalf of the sovereign of the dynasty of Seljuk, or Seljuk, Sultan ("tarihiSoltani") era (Katanov N. F., 1920).

As the indirect indicator of the use of the Iranian calendar in the Volga Bulgaria is the fact that in the past the New Year's month was called in Persian: "Newroz"(new day) by the people of the Middle Volga region (see table $2)$.

Table 2. Comparative table of month names calendar of the people of the Middle Volga region

\begin{tabular}{|c|c|c|c|}
\hline Tatar & Chuvash & Mari & Translation into Russian \\
\hline 1. Neuruz & $\begin{array}{l}\text { Nuras (Naras), } \\
\text { Nurs (Nars) }\end{array}$ & Neuruz & $\begin{array}{l}\text { from Persian-«novyiy den»; «mesyats novogo goda, } \\
\text { dnya» } \\
\text { the literal translation into English: "new day"; "the } \\
\text { month of the new year, day" }\end{array}$ \\
\hline 2. Bush & Pusha (Posha) & Pozh & $\begin{array}{l}\text { svobodnyiy mesyats } \\
\text { the literal translation into English: free month }\end{array}$ \\
\hline 3. Saban & Aka & Aga & $\begin{array}{l}\text { mesyats pashni, sohi, pluga } \\
\text { the literal translation into English: the month of arable } \\
\text { land, the plow, plough }\end{array}$ \\
\hline 4. zhey & $\mathrm{Su}$ & & $\begin{array}{l}\text { mesyats leta } \\
\text { the literal translation into English: summer month }\end{array}$ \\
\hline 5. Bilek, Chertmђ & Sertme & & $\begin{array}{l}\text { pyatyiy parovoy mesyats } \\
\text { the literal translation into English: the fifth steam } \\
\text { month }\end{array}$ \\
\hline 6. Pechђn & Uta & Uta & $\begin{array}{l}\text { mesyats sena, senokosa } \\
\text { the literal translation into English: the month of hay, } \\
\text { haymaking }\end{array}$ \\
\hline 7. Urak & Surla & Ursho-sorla & $\begin{array}{l}\text { mesyats serpa, zhatvyi } \\
\text { the literal translation into English: the month of the } \\
\text { sickle, harvest }\end{array}$ \\
\hline
\end{tabular}




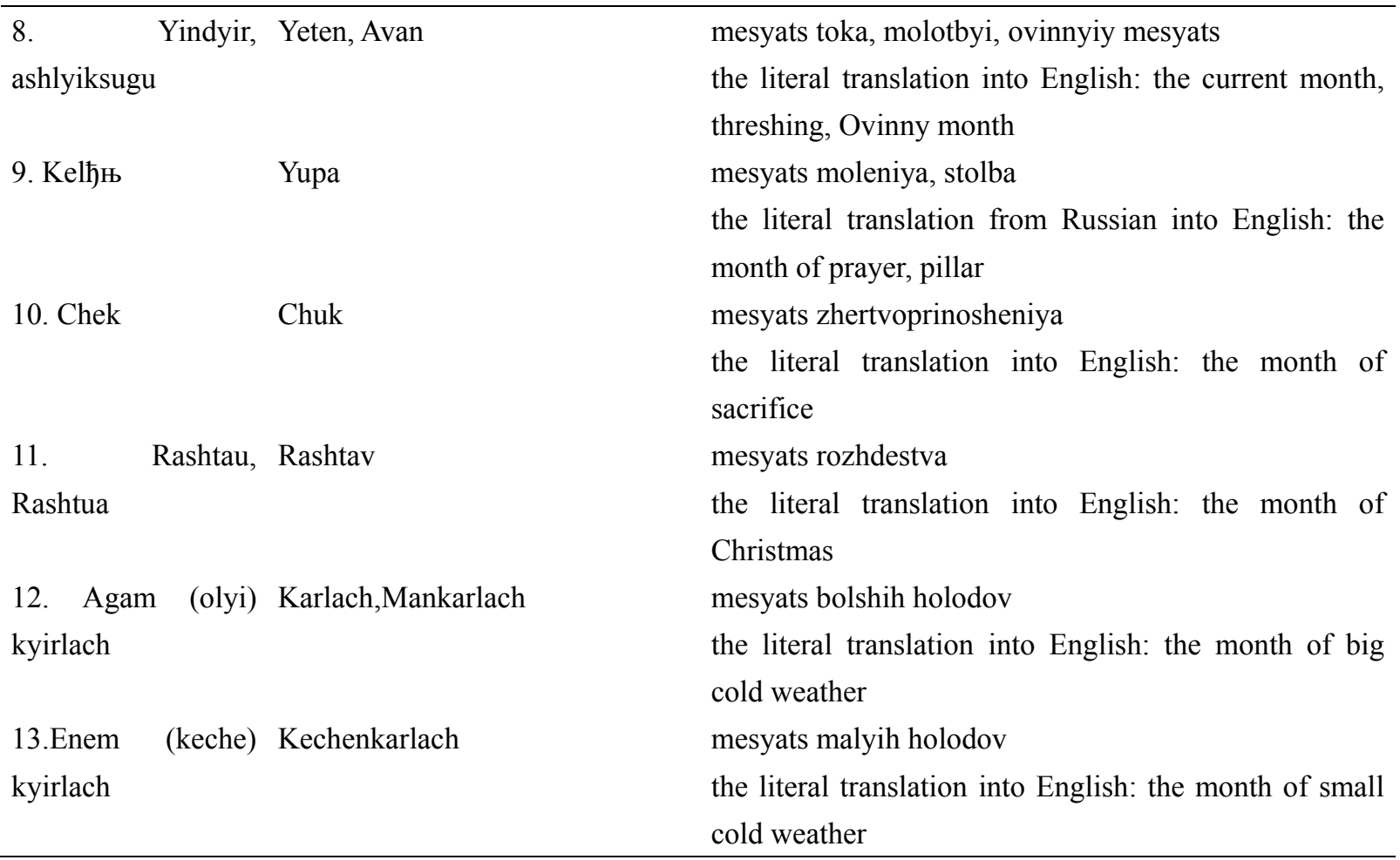

The table is compiled according to: "The Tatars of the Middle Volga region and Cisurals" (1967), «Tatar telenen dialektologik suzlege» (1969), R. G. Ahmetyanov (1981), V. M. Berkutov (1987), F. S. Bayazitova (1986), V. D. Dimitriev (1982) and others.

The "Hamal notation" means "solar Hijri" - the zodiac calendar (year consisted of months, which were the names of the constellations of the Zodiac), which existed from the XI century. This calendar was based on the visible motion of the sun on the ecliptic. Within 12 months the sun passes through 12 constellations. The first month of this calendar was called the chronology (the month of Aries coincides with March). The folklore materials of the Kazan Tatars show that this calendar system was popular among the rural population because it, noting the time of the solar year, quite accurately regulated the order of the agricultural work. The Tatar national proverbs and signs testify to it.

Thus, the Volga Bulgars recorded the following chronology: 1) the Turko-Mongolian on the basis of the twelve-year animal cycle, 2) actually the Bulgar luni-solar calendar, 3) the Muslim zodiac "solar Hijri", 4) the Muslim lunar Hijri, 5) the Iranian solar calendar. The Bulgarian scientists were familiar with other calendars. Calendars were in close relation with other areas of spiritual culture (folklore, signs, myths, etc.).

\section{Conclusion}

Review of calendars for a long historical time allowed to come to the conclusion that they are virtually without change could have survived for very long. Particularly systems of time account proved to be stable, which appeared in the period of the Turkic Kaganate, though certain changes corresponding to the conditions and requirements of the time are observed.

In the Turko-Tatar societies calendars served not only as a "tool" of chronology, and closely intertwined with other areas of spiritual culture (astronomical and mathematical knowledge, folk signs, folklore, myths, etc.).

Close ties with other countries led to the penetration and assimilation of calendars of other nations (China, Iran, Central Asia, the Caucasus, the Muslim countries, to some extent the Byzantine Empire, Ancient Rus), but they were adapted to local conditions.

\section{Recommendations}

The article can be useful for a comprehensive, systematic study of the spiritual culture of the Turkic-Tatars. They can deeper reveal their economic and social life.

Observations of the movement of the sun, the moon, stars and planets led to the creation of astronomical 
calendars. It was this time theoretical generalization of observation of nature, celestial objects. Therefore, they contribute to a more complete disclosure of the status of mathematical and astronomical knowledge.

\section{Acknowledgement}

The work is performed according to the Russian Government Program of Competitive Growth of Kazan Federal University.

\section{References}

Ahmetyanov, R. G. (1981). Obschaya leksika duhovnoy kulturyi narodov Srednego Povolzhya. Moskva.

Bayazitova, F. S. (1986). Govoryi tatar-kryashen v sravnitelnom osveschenii. Moskva: "Nauka".

Berkutov, V. M. (1987). Narodnyiy kalendar i metrologiya bolgaro-tatar. Kazan: Tatknigoizdat.

Berkutov, V. M. (1997). Razvitie matematicheskogo obrazovaniya bolgaro-tatar. Kazan.

Bichurin, N. Ya. (Iakinf). (1950). Sobranie svedeniy o narodah, obitavshih v Sredney Azii v drevnie vremena. Moskva-Leningrad: Izdatelstvo AN SSSR, T.2. (58).

Biruni Abureyhan. (1957). Pamyatniki minuvshih pokoleniy. Izbrannyie proizvedeniya.Tashkent: Izdatelstvo AN Uz. SSR. T.1.XXXV.

Dimitriev, V. D. (1982). Chuvashskiy kalendar i metrologiya. Cheboksaryi.

Drevnetyurkskiy slovar. (1969). Leningrad: Izdatelstvo «Nauka». (215, 266, 281, 605).

Flerova, V. E. (1997). Narodnyiy kalendar Hazarii. Kulturyi stepey Evrazii vtoroy polovinyi I tyisyacheletiya n.e. (voprosyi hronologii)/Tezisyi dokladov II Mezhdunarodnoy arheologicheskoy konferentsii 17-20 noyabrya 1997 g. Samara (48-51).

Katanov, N. F. (1920). Vostochnaya hronologiya. Kazan, 212.

Khisamutdinov, G. M. (1967). Glava XI. Narodnyie znaniya. Tataryi Srednego Povolzhya i Priuralya. Moskva: Nauka, (327-329; 331-332)

Koshgari Mahmud. (1960). Devonu lugatitturk. Tashkent. V 3-h tt. T. 1.

Malov, S. E. (1951). Pamyatniki drevnetyurkskoy pismennosti. Moskva: Izdatelstvo AN SSSR, 28.

Malov, S. E. Pamyatniki drevnetyurkskoy pismennosti Mongolii i Kirgizii. Moskva-Leningrad: Izdatelstvo AN SSSR. $(20-21,25)$.

Melioransky, P. M. (1899). Pamyatnikv chest Kyul-tegina. Sankt Peterburg, 141.

Mikolla, I. I. (1916). Hronologiya dunayskih bolgar (tyurkskogo plemeni). Izvestiya obschestva arheologii $i$ etnografii pri Kazanskom universitete, 29-4.

Opryshko, O. L. (1967). Starye kalendarnye sistemy kabardineev i balkareev. Uchenye zapiski Kabardino-balkarskogo Nauchno-issledovatel'skogo instituta, T. 24.

Samoylovich, A. N. (1927). K voprosu o dvenadtsatiletnem zhivotnom tsikle u turetskih narodov. Vostochnyie zapiski. Leningrad.1. (156-162).

Shanskiy, N. M., Ivanov, V. V., \& Shanskaya, T. V. (1971). Kratkiy etimologicheskiy slovar russkogo yazyika. Moskva: Izdatelstvo «Nauka». Leningradskoe otdelenie.

Tikhomirov, M. N. (1946). Imennik bolgarskih knyazey. Vestnik drevney istorii, 3.

\section{Copyrights}

Copyright for this article is retained by the author(s), with first publication rights granted to the journal.

This is an open-access article distributed under the terms and conditions of the Creative Commons Attribution license (http://creativecommons.org/licenses/by/3.0/). 